\title{
Changes in the Material Characteristics of Maize Straw during the Pretreatment Process of Methanation
}

\author{
Yongzhong Feng, ${ }^{1,2}$ Xiaoling Zhao, ${ }^{1,2}$ Yan Guo, ${ }^{2,3}$ Gaihe Yang, ${ }^{1,2}$ Jianchao Xi, ${ }^{4}$ \\ and Guangxin Ren ${ }^{1,2}$ \\ ${ }^{1}$ College of Agronomy, Northwest A\&F University, P.O. Box 95, Yangling, Shaanxi 712100, China \\ ${ }^{2}$ The Research Center of Recycle Agricultural Engineering and Technology of Shaanxi Province, Yangling, Shaanxi 712100, China \\ ${ }^{3}$ College of Forestry, Northwest A\&F University, Yangling, Shaanxi 712100, China \\ ${ }^{4}$ Institute of Geography Sciences and Natural Resources Research, Chinese Academy of Sciences, Beijing 100101, China
}

Correspondence should be addressed to Yongzhong Feng, fengyz@nwsuaf.edu.cn

Received 26 March 2012; Revised 30 July 2012; Accepted 30 July 2012

Academic Editor: Anuj K. Chandel

Copyright ( $) 2012$ Yongzhong Feng et al. This is an open access article distributed under the Creative Commons Attribution License, which permits unrestricted use, distribution, and reproduction in any medium, provided the original work is properly cited.

\begin{abstract}
Pretreatment technology is important to the direct methanation of straw. This study used fresh water, four bacterium agents (stem rot agent, "result" microbe decomposition agent, straw pretreatment composite bacterium agent, and complex microorganism agent), biogas slurry, and two chemical reagents (sodium hydroxide and urea) as pretreatment promoters. Different treatments were performed, and the changes in the straw $\mathrm{pH}$ value, temperature, total solid (TS), volatile solid (VS), and carbon-nitrogen ratio $(\mathrm{C} / \mathrm{N}$ ratio) under different pretreatment conditions were analyzed. The results showed that chemical promoters were more efficient than biological promoters in straw maturity. Pretreatment using sodium hydroxide induced the highest degree of straw maturity. However, its $\mathrm{C} / \mathrm{N}$ ratio had to be reduced during fermentation. In contrast, the $\mathrm{C} / \mathrm{N}$ ratio of the urea-pretreated straw was low and was easy to regulate when used as anaerobic digestion material. The biogas slurry pretreatment was followed by pretreatments using four different bacterium agents, among which the effect of the complex microorganism agent (BA4) was more efficient than the others. The current study is significant to the direct and efficient methanation of straw.
\end{abstract}

\section{Introduction}

The rural household biogas in China has rapidly developed in recent years. By 2010, the number of rural household biogas users had reached 41.8 million in China $[1,2]$. However, the rural household biogas industry has been facing a fermented material shortage due to the changes in agricultural structure. Moreover, the use of anaerobic digesters has been discontinued due to material shortage [3-5]. In China, the straw yield is nearly $7 \times 10^{9} \mathrm{t}$ every year $[6,7]$ (of which rice, corn, and wheat straw account for $79.5 \%$ ) [8]. Aside from the small portions used as animal feeds or returned to the field, most straws are either used as fuels or burned directly in the fields, which cause a huge waste [9-11]. However, straw as fermented material possesses many problems, such as long run-up time, low gas output, low material utilization ratio, and material crusting $[12,13]$. Crop straw has high contents of lignin, cellulose, and hemicellulose, and the degradation is difficult. These problems seriously affect the fermentation process and material processing of straw [14]. Therefore, straw pretreatment is essential for an efficient direct methanation.

Maize straw is a lignocellulosic biomass which contains components such as cellulose $(34.0 \%)$, hemicellulose $(37.5 \%)$, and lignin (22\%). The carbon-nitrogen ratio $(\mathrm{C} / \mathrm{N}$ ratio) for maize straw is about $66.31 \%$, while the proper $\mathrm{C} / \mathrm{N}$ ratio for anaerobic digester should be within the range of 25-35 [15]. At present, straw pretreatment studies focus on adjusting the nutritional value of straw and improving its characteristics $[16,17]$. Adjusting the nutritional value 
is usually achieved by regulating the $\mathrm{C} / \mathrm{N}$ ratio by mixing straw with fermented materials having different carbon and nitrogen contents. Therefore, exogenous nitrogen needs to be supplemented to increase the nitrogen fraction for more efficient anaerobic digestion of maize straw. Nitrogen can be added in the form of inorganic form (e.g., ammonium bicarbonate) or organic form (e.g., urea or animal manure). Animal manure and other organic wastes are additional nutrient sources, provided they are readily available for anaerobic digestion. Nitrogen fertilizer (e.g., ammonia or urea) is another nitrogen source that can be easily added to the maize straw if nitrogenous wastes are not available [18]. On the other hand, straw characteristics are improved by using physical, chemical, or biological pretreatment, which improve the straw's utilization rate [16]. Lignocellulose is difficult to degrade biologically. Pretreatment of straw by mechanical size reduction, heat treatment, and/or chemical treatment usually improves its digestibility. Chemical pretreatment methods that have been explored in previous research include bicarbonate treatment [19], radiation [20], alkaline peroxide treatment [21], and ammonia treatment [22]. Among them, ammonia treatment has several advantages over the other ones, since ammonia itself is a nitrogen source for biodegradation.

Based on the theory and practice of straw anaerobic digestion and rural methane fermentation, this study investigated $\mathrm{pH}$, temperature, total solid (TS), volatile solid (VS), and carbon-nitrogen ratio $(\mathrm{C} / \mathrm{N}$ ratio) of maize straw during biological and chemical pretreatment processes. Moreover, the changes in the material characteristics during the process were compared, and efficient straw pretreatment agents were chosen according to the degree of straw maturity. The current study also provides theoretical reference for practical methanation.

\section{Materials and Methods}

2.1. Raw Material. Air-dried maize straw used in this study was collected from the experimental field of Northwest Agriculture and Forestry University in Yangling, China. Before the pretreatment, the maize straw was chopped into $2-3 \mathrm{~cm}$ pieces [23]. The raw material contained $79.50 \pm 0.42 \%$ of TS, and there were about $89.20 \%$ VS in the dry matter. The $\mathrm{C} / \mathrm{N}$ ratio of the raw material was 66.31 .

2.2. Biological Pretreatment. The biological pretreatment promoters were mixed microorganism, which were bacterium agent 1(BA1) [24] (stem rot agent, main composition: Bacillus polymyxa, Bacillus subtilis, Bacillus brevis, Bacillus licheniformis, Brevibacterium sulphureum, and so on.), bacterium agent 2(BA2) [25] ("result" microbe decomposition agent, main composition: Saccharomyces cerevisiae, Coccidioides, H. anomala, S. cerevisiae, Bacillus licheniformis, Pseudomonas, Leucothrix, Lactobacillus delhi and so on.), bacterium agent 3(BA3) [26] (straw pretreatment composite bacterium agent, main composition: Bacillus subtilis, Streptomyces microflavus, Trichoderma koningii, Chaetomium globosum, and so on.), and bacterium agent 4(BA4) [27] (complex microorganism agent, main composition: Bacillus subtilis, Bacillus natto, Streptoverticillium baldaccii, Thermoactinomyces vulgaris, Saccharomyces cerevisiae, Candida utilis, Candida tropicalis, Aspergillus niger, Aspergillus oryzae, Rhizopus nigricans, and so on.).

These four kinds of microorganism were weighed 0.04, $8.00,8.00$, and $8.00 \mathrm{~g}$, respectively, according to their different number of viable bacteria. Then these pretreatment promoters were put into four different $2000 \mathrm{~mL}$ beakers, which contain $2000 \mathrm{~g}$ fresh water. After that, the mixer was put into a constant temperature incubator for a $24 \mathrm{~h}$ cultivation in $37^{\circ} \mathrm{C}$ [28]. The activated promoters were then added into the pretreatment reactor, which contained $800 \mathrm{~g}$ maize straw. The pretreatment process was 10 days.

Biogas slurry was obtained from an anaerobic digester that produced gas normally in Yangling, China. $2000 \mathrm{~g}$ biogas slurry was added in the pretreatment reactor with $800 \mathrm{~g}$ maize straw, and the pretreatment process was 10 days.

2.3. Chemical Pretreatment. Sodium hydroxide and urea were used in this study. The amount of chemicals added was referred to in the previous researches $[29,30]$. This study added $800 \mathrm{~g}$ maize straw, $2000 \mathrm{~g}$ fresh water, and then $160 \mathrm{~g}$ sodium hydroxide and $160 \mathrm{~g}$ urea, respectively. The pretreatment process lasted for 10 days.

In this study, fresh water was used as the control group, and $2000 \mathrm{~g}$ was added into $800 \mathrm{~g}$ maize straw for a ten-day pretreatment. All operations were of unified management, and the experiment was repeated three times.

2.4. Tested Indexes and Methods. The $\mathrm{pH}$ value was measured by intelligent $\mathrm{pH}$ meter (pHs-3CT, China) every day. Temperatures at the center of each pile as well as environmental temperature were recorded manually by a thermometer every day. The untreated and treated maize straw samples were analyzed for TS and VS, according to the APHA standard methods [31]. The total organic carbon (TOC) was determined using the $\mathrm{K}_{2} \mathrm{Cr}_{2} \mathrm{O}_{7}$ volumetric and outside heating methods [32]. The total organic nitrogen (TON) was analyzed by Kjeldahl method (Model KDN-08C, Shanghai, China) as recommended by Cottenie et al. [33], while the carbon-nitrogen $(\mathrm{C} / \mathrm{N})$ ratio was calculated using values of the TOC and TON.

\section{Results}

3.1. Changes in the Physical and Chemical Characteristics of Maize Straw before and after Pretreatment. The characteristics of maize straw between before pretreatment and after ten-day pretreatment were compared in Table 1. After pretreatment, TS of maize straw was dramatically decreased, which was between $11.07 \pm 1.33 \%$ and $20.00 \pm 0.30 \%$. Significant differences were observed between control group $(11.53 \pm 0.55 \%)$ and experimental groups, except those treated with BA1 $(11.07 \pm 1.33 \%)$ and BA2 $(11.83 \pm 0.21 \%)$. An extremely significant difference was also observed between the control group and the specimens pretreated with BA4 $(14.31 \pm 0.37 \%)$, 
TABLE 1: Basic characteristics of maize straw before and after ten-day pretreatment.

\begin{tabular}{|c|c|c|c|c|c|c|}
\hline \multicolumn{2}{|c|}{ Pretreatment promoters } & $\mathrm{TS}^{\mathrm{a}}(\%)$ & $\mathrm{VS}^{\mathrm{b}}(\%)$ & $\operatorname{TOC}^{\mathrm{c}}(\%)$ & $\operatorname{TON}^{\mathrm{d}}(\%)$ & $\mathrm{C} / \mathrm{N}$ ratio \\
\hline \multicolumn{2}{|l|}{ Raw material } & $79.50 \pm 0.42$ & $89.20 \pm 0.31$ & $36.95 \pm 0.28$ & $0.56 \pm 0.02$ & 66.31 \\
\hline \multirow{8}{*}{ After ten-day pretreatment } & BA 1 & $11.07 \pm 1.33$ & $92.33 \pm 0.45$ & $33.00 \pm 0.43$ & $0.54 \pm 0.00$ & 61.05 \\
\hline & BA 2 & $11.83 \pm 0.21$ & $91.65 \pm 0.64$ & $33.78 \pm 0.41$ & $0.72 \pm 0.05$ & 46.68 \\
\hline & BA 3 & $13.67 \pm 0.23$ & $90.36 \pm 0.37$ & $34.69 \pm 0.55$ & $0.68 \pm 0.05$ & 50.90 \\
\hline & BA 4 & $14.31 \pm 0.37$ & $89.64 \pm 0.27$ & $32.50 \pm 0.30$ & $0.70 \pm 0.03$ & 46.53 \\
\hline & Urea & $14.64 \pm 0.60$ & $91.24 \pm 0.32$ & $32.43 \pm 0.43$ & $1.45 \pm 0.02$ & 22.36 \\
\hline & Sodium hydroxide & $20.00 \pm 0.30$ & $44.63 \pm 0.45$ & $15.03 \pm 0.24$ & $0.25 \pm 0.02$ & 60.25 \\
\hline & Biogas slurry & $13.71 \pm 0.34$ & $86.11 \pm 0.39$ & $28.00 \pm 0.08$ & $0.84 \pm 0.00$ & 33.23 \\
\hline & Fresh water & $11.53 \pm 0.55$ & $93.19 \pm 0.38$ & $33.37 \pm 0.54$ & $0.59 \pm 0.01$ & 56.26 \\
\hline
\end{tabular}

${ }^{\mathrm{a}}$ TS: total solid.

${ }^{\text {b}}$ VS: volatile solid, dry basis.

${ }^{c}$ TOC: total organic carbon, dry basis.

dTON: total organic nitrogen, dry basis.

ure $(14.64 \pm 0.60 \%)$, andsodiumhydroxide $(20.00 \pm 0.30 \%)$. The VS content of the sodium hydroxide-treated specimen $(44.63 \pm 0.45 \%)$ was significantly different from that of the raw material $(89.20 \% \pm 0.31)$, while VS of the other treatments fluctuated between $86.11 \pm 0.39 \%$ and $93.19 \pm$ $0.38 \%$ without substantial change. Compared with raw material, TOC of all experimental groups decreased. TOC of the sodium hydroxide-treated specimen was only $15.03 \pm$ $0.24 \%$, indicating that majority of water-insoluble carbon was decomposed and transformed during the pretreatment process. TON of the groups treated with BA1 $(0.54 \%)$ and sodium hydroxide $(0.25 \pm 0.02 \%)$ both decreased, while others increased. The $\mathrm{C} / \mathrm{N}$ ratios of the pretreated straws were lower than that of the raw material, implying that pretreatment reduces the $\mathrm{C} / \mathrm{N}$ ratio of fermented materials, which is significant to the life activities of methanogenic bacteria.

3.2. Changes in $\mathrm{pH}$. $\mathrm{pH}$ plays a crucial role in the growth metabolism of microbes. Microorganism used in this study was a mixture which contained bacterium, fungus, saccharomycetes, and actinomycetes, with its suitable $\mathrm{pH}$ varying from 4.5 to 6.5 . $\mathrm{pH}$ of $\mathrm{BA} 1$ treated decreased to the range of 4.1 to 4.8 from the 5 th day, which is unfavorable for bacterium growth. $\mathrm{pH}$ of BA2 treated fell to 4.4 on the 4 th day. However, it gradually increased later, and hence, the bacterium activity significantly decreased. $\mathrm{pH}$ of BA3 treated was stable between 4.7 and 6.2 before the 8th day. However, $\mathrm{pH}$ was then decreased to 4.3 at the 9th day and kept at the same level at the 10th day. $\mathrm{pH}$ of BA4 treated remained between 4.7 and 5.9. Thus, the bacterium grew well under the moderate conditions. Compared with that of control group, $\mathrm{pH}$ of biogas slurry-treated group was higher at the first two days. Then, it started to decline three days later and stabilized between 6.15 and 7.75, maintaining a neutral condition, which fell in the scope of the suitable $\mathrm{pH}$.

$\mathrm{pH}$ of two chemically treated specimens was both higher than the others, particularly between 8.9 and 9.2 and between 11.3 and 11.8 for the urea and sodium hydroxidetreated groups, respectively. $\mathrm{pH}$ of control group was kept

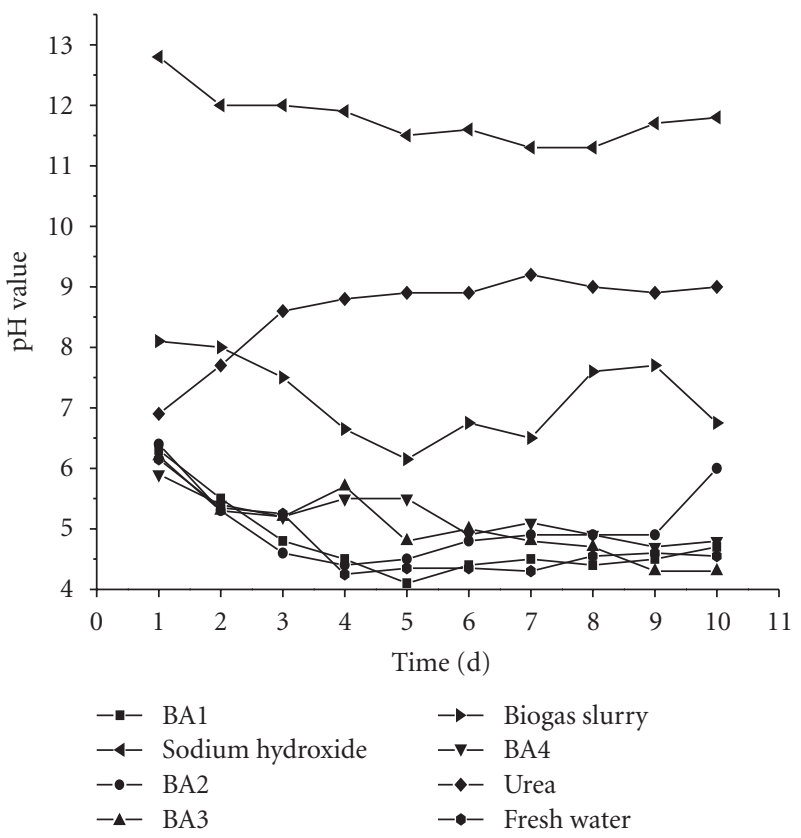

Figure 1: Changes in $\mathrm{pH}$ level during the pretreatment process.

falling down and then fluctuated near 4.4 since the 4th day (Figure 1).

3.3. Changes in Temperature. Temperatures of the environment and every treated group were shown in Figure 2. The temperature of the environment significantly changed during the 6th and 8th days, whereas those of the treated groups did not. The temperature of the group treated with BA1 was slightly lower than that of environment during the 3 rd and 5th days, whereas the other bacterium agents groups had higher temperatures than that of environment. This result can be attributed to the restrained growth of BA1 due to the interaction of the $\mathrm{pH}$ and temperature during the process, which thus causes the decline of the decomposition characteristics of the material. The temperatures 


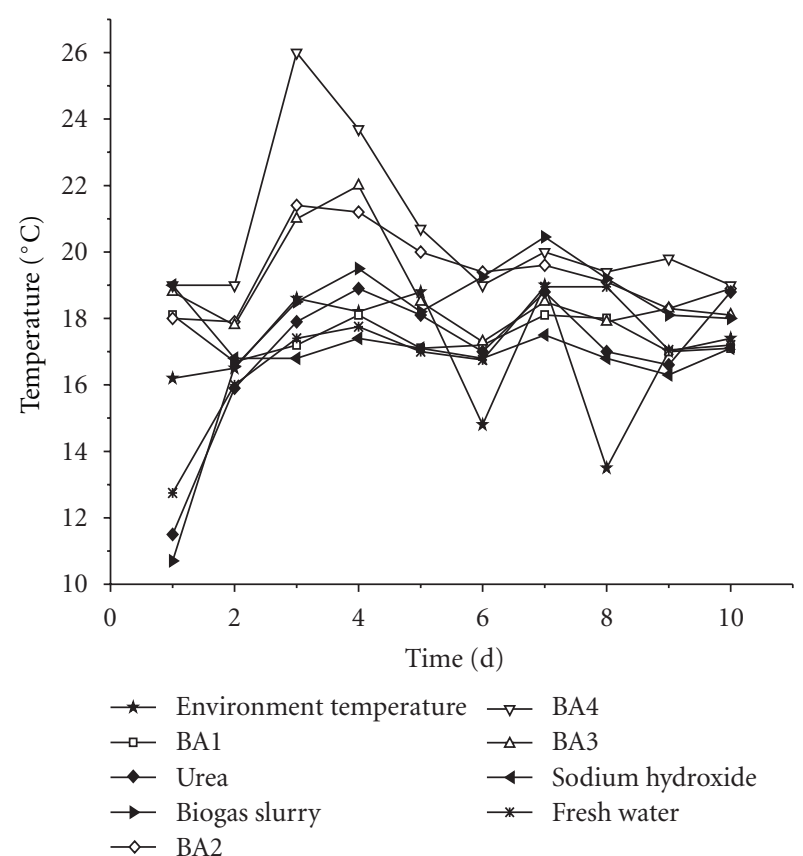

FIgURE 2: Changes in the temperature during the pretreatment process.

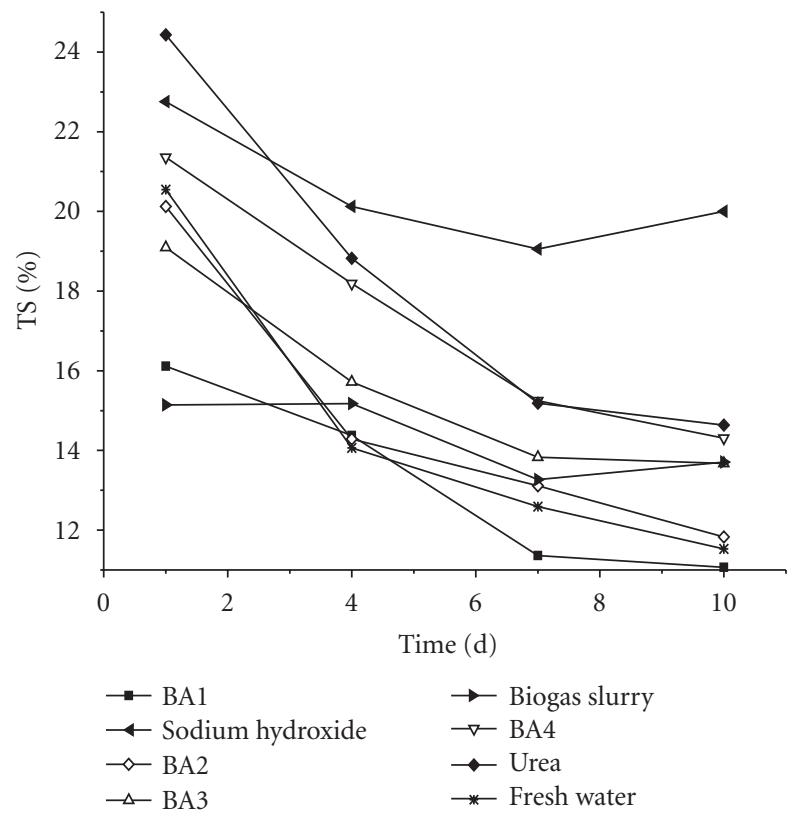

Figure 3: Changes in the TS content during the pretreatment process.

of the groups treated with BA3 and BA4 were high and thus beneficial to the straw decomposition. Moreover, the temperatures of the two chemically treated groups slightly fluctuated along the temperature of environment. During the 1st day, the temperature of the urea-treated group was quite low (only $11.5^{\circ} \mathrm{C}$ ) and that of the sodium hydroxide-treated group was higher $\left(19.0^{\circ} \mathrm{C}\right)$. Both seemed to stabilize after that and, hence, were beneficial for the organic decomposition

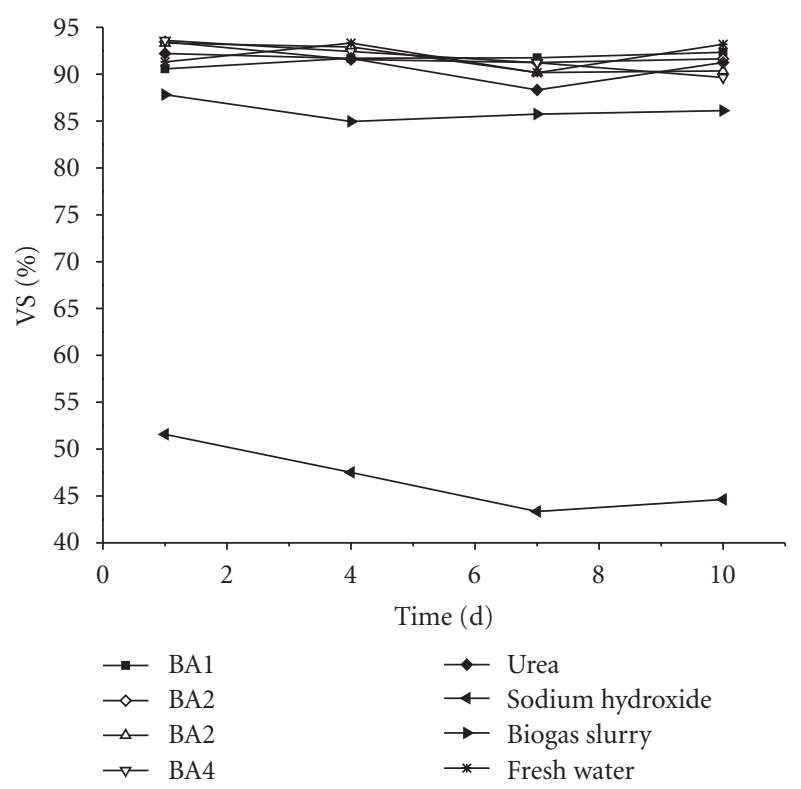

Figure 4: Changes in the VS content during the pretreatment process.

in straw. The temperatures of the biogas-slurry-treated and control groups were subject to the environment.

3.4. Changes in TS and VS. TS and VS are two indexes of the degree of decomposition maturity and are important parameters of the fermented substrate concentration. Figure 3 showed that the TS contents of all experimental groups were higher than that of the control group since the 4th day, indicating the effect of the promoters on straw decomposition. However, these TS contents all decreased as time elapsed. During the 1st day, the TS content of the ureatreated group was the highest, followed by that of the sodium hydroxide-treated group. However, the former declined by $9.79 \%$, whereas the latter decreased by only $2.1 \%$. Among the biological promoters, TS of the group treated with BA4 was higher than those of the others, whereas those of the groups treated with BA1 and biogas slurry stayed at low levels without significant changes. In summary, during the pretreatment process, the two chemical promoters induced the highest degrees of straw decomposition maturity, whereas BA4 and BA1 and biogas slurry had lesser effects.

Figure 4 showed the changes in VS. VS of all groups stabilized between $88.31 \%$ and $93.61 \%$ without significant fluctuations and differences, except those of the groups treated with sodium hydroxide and biogas slurry. VS of the sodium hydroxide-treated group was the lowest $(43.35 \%$ to $51.18 \%$ ), followed by that of the group with biogas slurry ( $84.95 \%$ to $87.80 \%)$, with slight fluctuations.

3.5. Changes in $C / N$ Ratio. $\mathrm{C} / \mathrm{N}$ ratio (Figure $5(\mathrm{a})$ ) of pretreated straw increased firstly and decreased subsequently, and had the same trend as TOC (Figure 5(b)). However, TON (Figure 5(c)) varied slightly except urea-treated group. Urea as a rich nitrogen promoter added exogenous nitrate in 


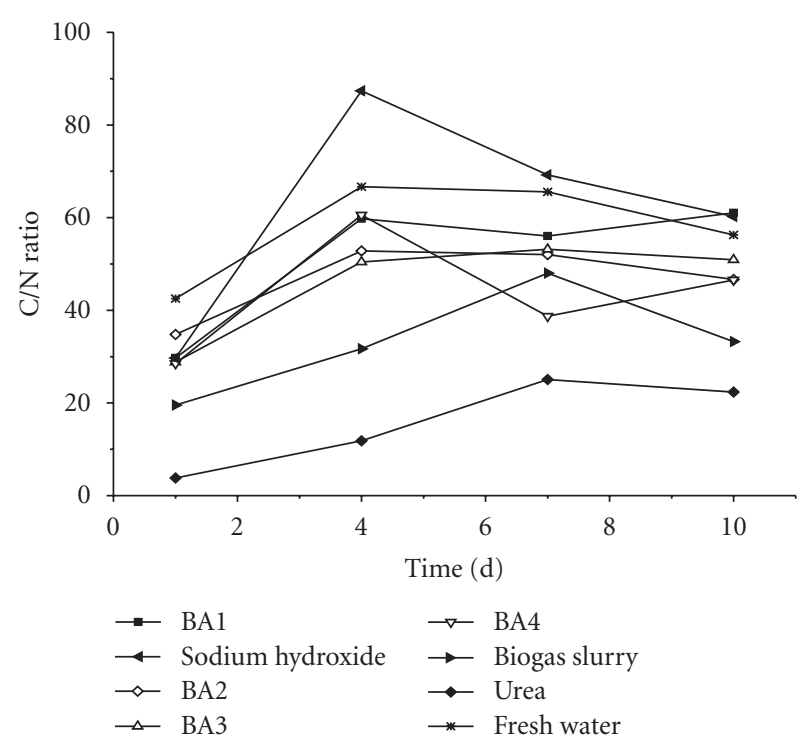

(a)

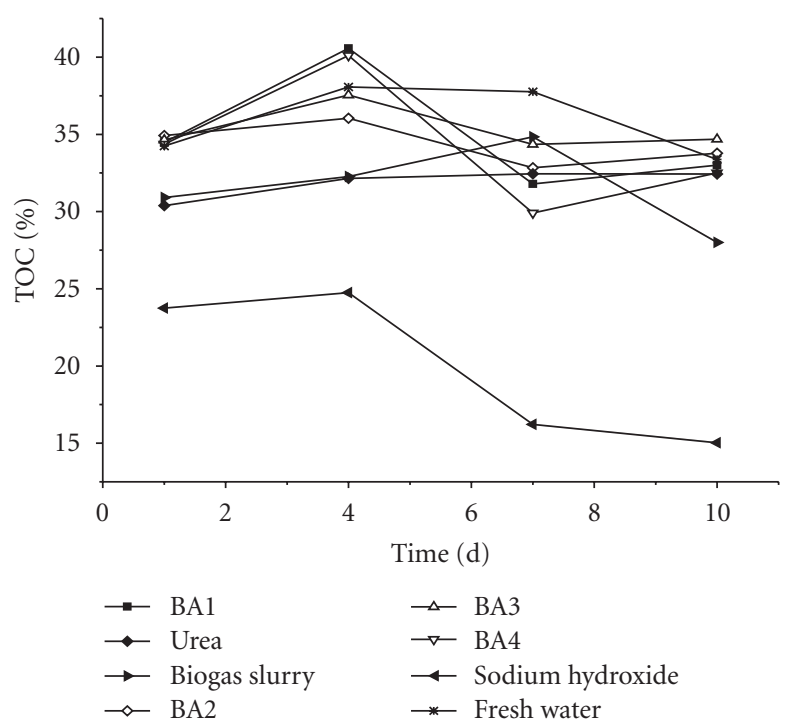

(b)

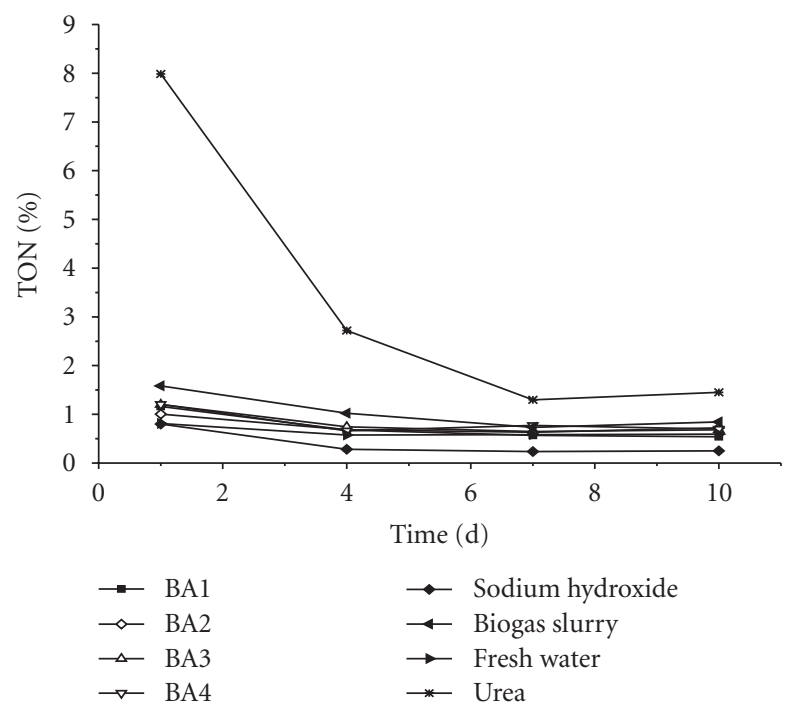

(c)

FIGURE 5: Changes in $\mathrm{C} / \mathrm{N}$ ratio, TOC, and TON during the pretreatment process: (a) changes in $\mathrm{C} / \mathrm{N}$ ratio, (b) changes in TOC, (c) changes in TON.

material. So $\mathrm{C} / \mathrm{N}$ ratio of urea-treated group was the lowest from beginning to end. Its $\mathrm{C} / \mathrm{N}$ ratio was only 3.80 on the $1 \mathrm{st}$ day. However, it gradually increased with time and remained between 3.80 and 22.36. $\mathrm{C} / \mathrm{N}$ ratios of BA1-treated, sodium hydroxide-treated, and control groups were very high during and after pretreatment, which were 51.65, 61.64, and 57.76 in average, respectively. In biological pretreatment, BA2, BA3, and BA4 treated had the same value in TOC and TON, and the $\mathrm{C} / \mathrm{N}$ ratio was very close to $46.58,45.86$, and 43.59 in average, respectively. For its lower TOC and higher TON, $\mathrm{C} / \mathrm{N}$ ratio of biogas slurry-treated group was kept at a lower level (33.12 in average). And the same results were achieved by Zhong et al. [34].

\section{Discussions}

Straw maturity is a key factor of the pretreatment. Several authors have concluded that using a single parameter as a maturity index is insufficient and that amalgamation of several parameters is usually needed. Various physical, biological, and chemical parameters have been used to monitor the quality and maturity of compost [35-37]. The effects of different promoters on the changes of the indexes during the pretreatment process varied, as well as the requirements of the different promoters on the pretreatment external conditions. Only in suitable temperatures, $\mathrm{pH}$ levels, and other environment conditions can bacterium agents 
obtain good effects. Too high or low temperatures and unsuitable $\mathrm{pH}$ levels can impede the normal life metabolism of microorganisms and thus influence the degree of straw decomposition maturity during the pretreatment process [38]. For the group treated with the stem rot agent (BA1), $\mathrm{pH}$ level of the material was lower during the early stages and was even as low as 4.1 during the 5 th day. The temperatures on the $3 \mathrm{rd}$ and 5 th days were lower than the environmental temperature, thus restraining the growth of microorganism and negatively affecting the straw organic degradation. Complex microorganism agent- (BA4-) treated group could maintain a better living condition for microbe, and its treatment effect was superior to other bacterium agent treatments. Urea and sodium hydroxide are both alkaline and, hence, beneficial to the degradation of lignocellulose and hemicellulose. Studies results showed that sodium hydroxide treatment can improve the conversion rate of lignocelluloses [39-47]. Moreover, the results of the studies by Chandra and Jackson [29] and Chesson [48] suggested that the degradation of lignocellulose was optimal upon the addition of $10 \%$ of sodium hydroxide. During the pretreatment process, the TS contents of the urea and sodium hydroxide-treated groups were both high. These results indicate that, under alkaline conditions, the lignocellulose degradation rate is improved, macromolecular substances are decomposed, the water-holding capacity of straw is decreased, and the water content of straw is lower than those of other samples of equivalent weight. The sodium hydroxide-treated group had an obviously lower VS content than those of the other groups. However, its $\mathrm{C} / \mathrm{N}$ ratio was higher. Thus, some restrictions were encountered when the group was used as fermented materials, and better effects could have been achieved by adding nitrogen to regulate the $\mathrm{C} / \mathrm{N}$ ratio to a suitable value. The biogas-slurry-treated group was more suitable for use in microorganism anaerobic fermentation, with only modest changes in the material's characteristics and a suitable $\mathrm{C} / \mathrm{N}$ ratio of 33.23 . The control group had a lower $\mathrm{pH}$ level, temperature, and TS content. Its $\mathrm{C} / \mathrm{N}$ ratio was higher, and the straw degradation was bad. Hence, its treatment effect was worse than those of the promoters.

\section{Conclusions}

Synthesizing each index of pretreatment material, it can be summarized that the effect of sodium hydroxide-pretreated group was better than any others, followed by urea-treated group. In biological pretreatment, biogas slurry was the best promoter, for its good corrosion effect, and more economic. BA4 also had a good effect on straw maturity, and the next is BA3 treated. BA1 treated was the worst group, because its microorganisms' survival conditions were limited by unsuited $\mathrm{pH}$ and temperature.

As compared with biological pretreatment, chemical treatment is easier to operate and has good effect. However, it will be a difficult and expensive task to recycle the chemicals used for the hydrolysis to avoid the environmental pollution. On the other hand, although the biological pretreatment was less effective than the sodium hydroxide and urea treatment, there exists a big room for improvement of the microbial degradation of cellulosic biomass by optimization of the fungal growth conditions and manipulation of the process parameters such as $\mathrm{pH}$ and temperature. However, in order to approach the biomass-to-fuels issue in a more environmentally friendly way, we will continue to improve the efficiency of biological treatment of maize straw to optimize the biogas production.

\section{Acknowledgments}

This study was financially supported by China's Technology Support Project for the Eleventh Five-Year-Plan: Research and Demonstration of the Key Technology on the Sustainable Development of Resettlement Area in Sanjiangyuan (Grant no. 2009BAC61B04) and the Twelfth Five-Year-Plan: High-yielded Biogas Technology Integrated Demonstration on Mixing Materials (Grant no. 2011BAD15B03) and the Special Energy Project by China's Ministry of Agriculture in 2012.

\section{References}

[1] X. J. Li, B. Zhou, H. R. Yuan, Y. Z. Pang, and Y. Meng, "China biogas industry-challenges and future development," Transactions of the Chinese Society of Agricultural Engineering, vol. 27, no. 2, pp. 352-355, 2011.

[2] Y. Z. Tu and Z. L. Wu, "Development report of China's biogas industry in 2010," Seminar corpus about methane development strategies and measures, 2010.

[3] Y. Q. Zhan, "Application of new techniques in methanation with material of straw," Renewable Energy Resources, vol. 25, no. 4, pp. 100-101, 2007.

[4] X. Z. Wang, "Discuss the causes and countermeasures of the declining use of methane in Pingan County," China Biogas, vol. 25, no. 4, pp. 47-48, 2007.

[5] Y. C. Huang, Y. Y. Lai, H. F. Xiong, L. M. Wen, M. H. Li, and J. H. Lai, "Discussion on feed-liquid separation technology of biogas," Energy Research and Management, vol. 3, pp. 68-70, 2010.

[6] L. Shi, Y. C. Zhao, and X. L. Chai, "Comprehensive utilization techniques progress of crop straws in China," China Biogas, vol. 23, no. 2, pp. 11-19, 2005.

[7] P. D. Zhang, Y. L. Yang, and G. Q. Li, "Energy potentiality of crop straw resources in China," Renewable Energy Resources, vol. 25 , no. 6 , pp. 80-83, 2007.

[8] X. J. Wang, G. H. Yang, Y. Z. Feng, G. X. Ren, and X. H. Han, "Optimizing feeding composition and carbon-nitrogen ratios for improved methane yield during anaerobic co-digestion of dairy, chicken manure and wheat straw," Bioresource Technology, vol. 27, pp. 1048-1053, 2012.

[9] Z. Y. Yan, Y. X. Yuan, X. F. Liu, Y. Z. Liao, and R. N. He, "A study on biogas fermentation with straws," Journal of Sichuan Agricultural University, vol. 27, no. 2, pp. 176-179, 2009.

[10] L. G. Yan and J. W. Chen, Several Major Problems of China's Energy Sustainable Development, Science Press, 2007.

[11] C. Z. Wu and L. L. Ma, Biomass Energy Modernization Utilization Technology, Chemical Industry Press, 2003.

[12] K. Sheng and Y. L. Zhang, "On sustainable development of the rural marsh gas construction in China," Journal of Huazhong Agricultural University, no. 4, pp. 50-52, 2007. 
[13] R. F. Li, C. L. Lan, B. Ma, and B. F. Shi, "Research progress of crude material on methane ferment," Chinese Agricultural Science Bulletin, vol. 27, no. 30, pp. 1-5, 2011.

[14] R. Liu, C. J. Wan, Q. Huang, and F. H. Huang, "Problem and prospect of pretreatment of straw," Environmental Science of Technology, vol. 32, no. 5, pp. 88-91, 2009.

[15] D. J. Hills and D. W. Roberts, "Anaerobic digestion of dairy manure and field crop residues," Agricultural Wastes, vol. 3, no. 3, pp. 179-189, 1981.

[16] X. H. Chen and H. G. Zhu, "Research progress and prospect on producing biogas from crop straws," Nongye Gongcheng Xuebao/Transactions of the Chinese Society of Agricultural Engineering, vol. 23, no. 3, pp. 279-283, 2007.

[17] Y. Wang, C. Lin, J. Hou, and Y. Hou, "Effects of bacterial protein and urea addition on straw anaerobic fermentation," Nongye Gongcheng Xuebao/Transactions of the Chinese Society of Agricultural Engineering, vol. 27, no. 1, pp. 74-78, 2011.

[18] R. Zhang and Z. Zhang, "Biogasification of rice straw with an anaerobic-phased solids digester system," Bioresource Technology, vol. 68, no. 3, pp. 235-245, 1999.

[19] J.-X. Liu, Y.-M. Wu, and N.-Y. Xu, "Effects of ammonia bicarbonate treatment on kinetics of fiber digestion, nutrient digestibility and nitrogen utilization of rice straw by sheep," Animal Feed Science and Technology, vol. 52, no. 1-2, pp. 131139, 1995.

[20] Lu Zhao Xin and M. Kumakura, "Effect of radiation pretreatment on enzymatic hydrolysis of rice straw with low concentrations of alkali solution," Bioresource Technology, vol. 43, no. 1, pp. 13-17, 1993.

[21] M. M. Patel and R. M. Bhatt, "Optimisation of the alkaline peroxide pretreatment for the delignification of rice straw and its applications," Journal of Chemical Technology and Biotechnology, vol. 53, no. 3, pp. 253-263, 1992.

[22] C. Sankat and B. Lauckner, "The effect of ammonia treatment on the digestibility of rice straw under various process conditions," Canadian Agricultural Engineering, vol. 33, no. 2, pp. 309-314, 1991.

[23] L. L. Chu, G. H. Yang, C. L. Zhang, G. X. Ren, and Y. Z. Feng, "The biogas production efficiency of crop straws at different temperature," Agricultural Research in the Arid Areas, vol. 26, no. 2, pp. 190-193, 199, 2008.

[24] B. He and E. X. Huang, "A crop straw rotten microbial agent and preparation method," China Patent, 2008.

[25] R. B. Duan, "Microbial decomposition agent and preparation method," China Patent, 2008.

[26] M. L. Li, J. Gu, H. Gao, Q. J. Qin, and D. L. Liang, "Microorganism preparation agent for fast maturity of agricultural residue and preparation method," China Patent, 2011.

[27] M. L. Li, J. Gu, and H. Gao, "Complex microorganism agent for fast maturity of agricultural residue and preparation method," China Patent, 2004.

[28] Y. M. Ji, G. H. Yang, D. X. Yin, and J. J. Liu, "Effect of different pretreatments on biogas production characteristics of anaerobic fermentation of wheat straw," Journal of Northwest A\&F University, vol. 40, no. 5, pp. 149-156, 2012.

[29] S. Chandra and M. Jackson, "A study of various chemical treatments to remove lignin from coarse roughages and increase their digestibility," The Journal of Agricultural Science, vol. 77, no. 1, pp. 11-17, 1971.

[30] R. K. Wilson and W. J. Pigden, "Effect of sodium hydroxide treatment on the utilization of wheat straw and poplar wood by rumen microorganisms," Canadian Journal of Animal Science, vol. 44, no. 1, pp. 122-123, 1964.
[31] American Public Health Association (APHA), Standard Methods for the Examination of Water and WasteWater, American Public Health Association (APHA), Washington, DC, USA, 1998.

[32] L. W. Lian, X. L. Wan, X. M. Guo et al., Routine Analysis of Methane Ferment, 1984.

[33] A. Cottenie, M. Verloo, L. Kiekens, G. Velghe, and R. Amerlynck, Chemical Analysis of Plants and Soils, Laboratory of Analytical and Agrochemistry State, University, Ghent, Belgium, 1982.

[34] W. Zhong, Z. Zhang, W. Qiao, P. Fu, and M. Liu, "Comparison of chemical and biological pretreatment of corn straw for biogas production by anaerobic digestion," Renewable Energy, vol. 36, no. 6, pp. 1875-1879, 2011.

[35] F. Zucconi, A. Pera, M. Forte, and M. de Bertoldi, "Evaluating toxicity of immature compost," BioCycle, vol. 22, no. 2, pp. 5457, 1981.

[36] C. Aparna, P. Saritha, V. Himabindu, and Y. Anjaneyulu, "Techniques for the evaluation of maturity for composts of industrially contaminated lake sediments," Waste Management, vol. 28, no. 10, pp. 1773-1784, 2008.

[37] M. Gómez-Brandón, C. Lazcano, and J. Domínguez, "The evaluation of stability and maturity during the composting of cattle manure," Chemosphere, vol. 70, no. 3, pp. 436-444, 2008.

[38] R. Y. Huang, W. N. He, H. J. Tang et al., "Straws biogas fermentation with bacterium additive pretreatment," China Biogas, vol. 26, no. 4, pp. 24-26, 2008.

[39] R. W. Detroy, L. A. Lindenfelser, S. Sommer, and W. L. Orton, "Bioconversion of wheat straw to ethanol: chemical modification, enzymatic hydrolysis, and fermentation," Biotechnology and Bioengineering, vol. 23, pp. 1527-1535, 1981.

[40] T. D. Nguyen, K. R. Kim, S. J. Han et al., "Pretreatment of rice straw with ammonia and ionic liquid for lignocellulose conversion to fermentable sugars," Bioresource Technology, vol. 101, no. 19, pp. 7432-7438, 2010.

[41] J. Cai, L. Zhang, S. Liu et al., "Dynamic self-assembly induced rapid dissolution of cellulose at low temperatures," Macromolecules, vol. 41, no. 23, pp. 9345-9351, 2008.

[42] S. Bower, R. Wickramasinghe, N. J. Nagle, and D. J. Schell, "Modeling sucrose hydrolysis in dilute sulfuric acid solutions at pretreatment conditions for lignocellulosic biomass," Bioresource Technology, vol. 99, no. 15, pp. 7354-7362, 2008.

[43] J. W. Lee and T. W. Jeffries, "Efficiencies of acid catalysts in the hydrolysis of lignocellulosic biomass over a range of combined severity factors," Bioresource Technology, vol. 102, no. 10, pp. 5884-5890, 2011.

[44] A. M. J. Kootstra, H. H. Beeftink, E. L. Scott, and J. P. M. Sanders, "Optimization of the dilute maleic acid pretreatment of wheat straw," Biotechnology for Biofuels, vol. 2, article 31, 2009.

[45] R. A. Silverstein, Y. Chen, R. R. Sharma-Shivappa, M. D. Boyette, and J. Osborne, "A comparison of chemical pretreatment methods for improving saccharification of cotton stalks," Bioresource Technology, vol. 98, no. 16, pp. 3000-3011, 2007.

[46] T. H. Kim, J. S. Kim, C. Sunwoo, and Y. Y. Lee, "Pretreatment of corn stover by aqueous ammonia," Bioresource Technology, vol. 90, no. 1, pp. 39-47, 2003.

[47] K. C. Nlewem and M. E. Thrash, "Comparison of different pretreatment methods based on residual lignin effect on the enzymatic hydrolysis of switchgrass," Bioresource Technology, vol. 101, no. 14, pp. 5426-5430, 2010.

[48] A. Chesson, "Effects of sodium hydroxide on cereal straws in relation to the enhanced degradation of structural polysaccharides by rumen microorganisms," Journal of the Science of Food and Agriculture, vol. 32, pp. 745-758, 1981. 

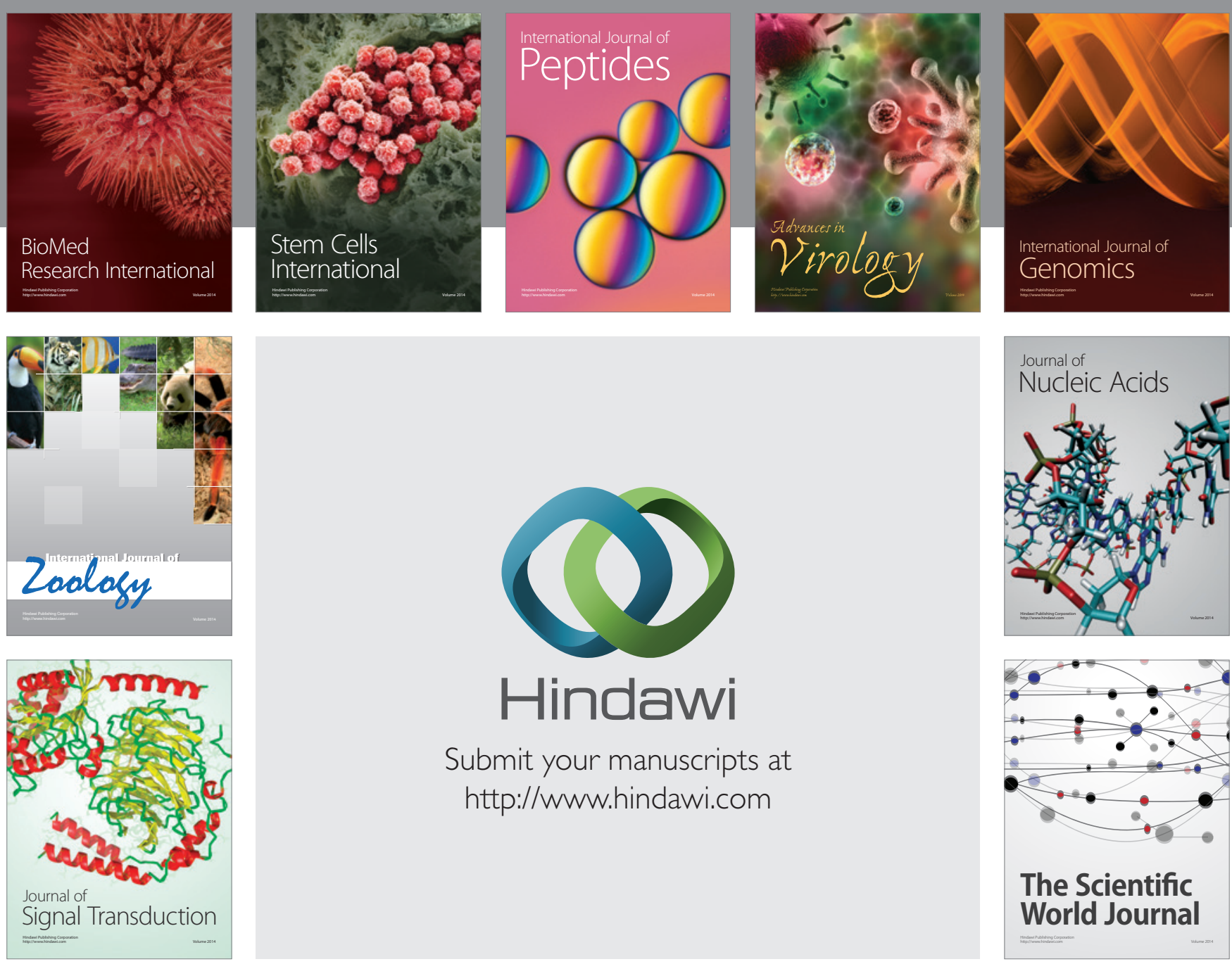

Submit your manuscripts at

http://www.hindawi.com
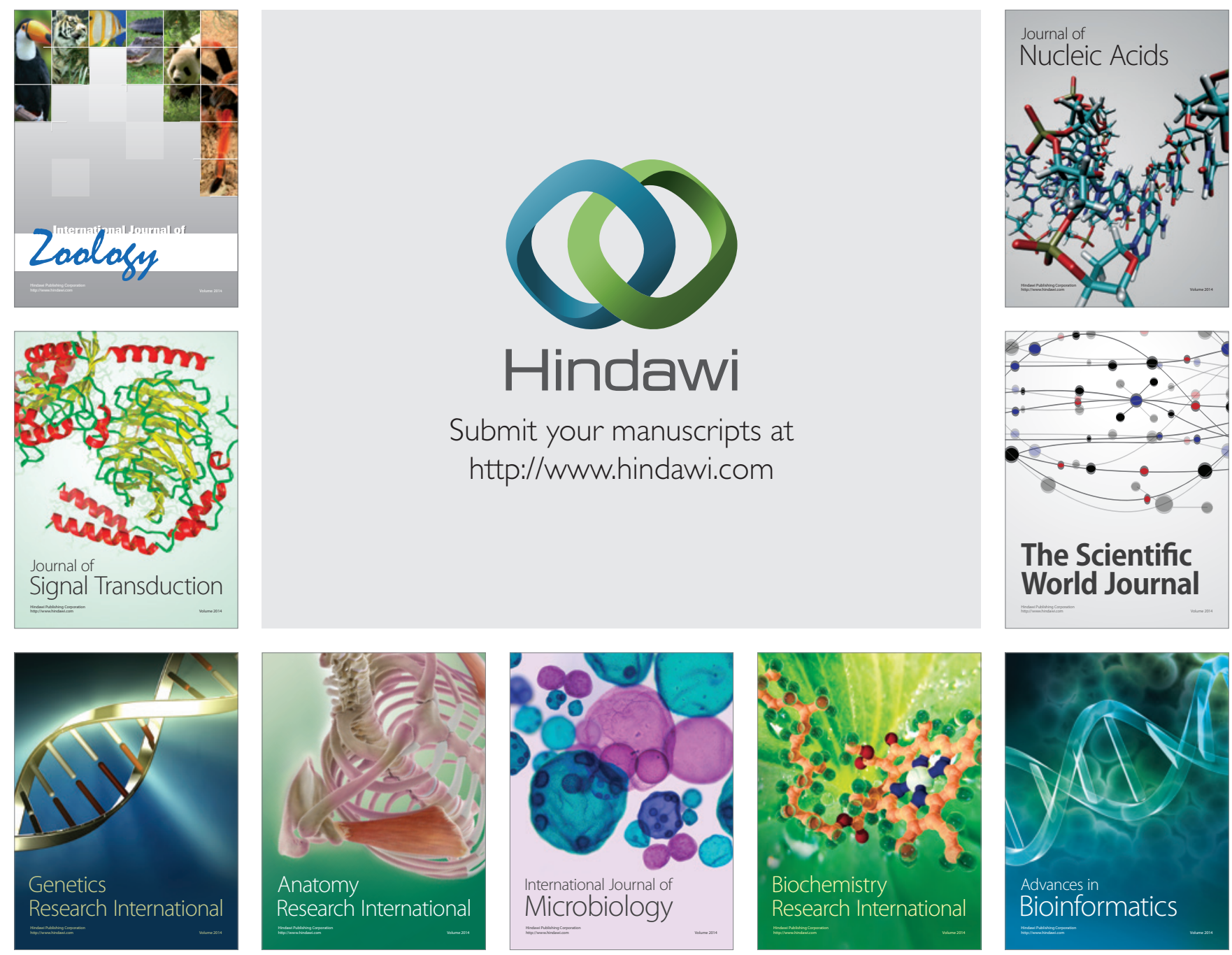

The Scientific World Journal
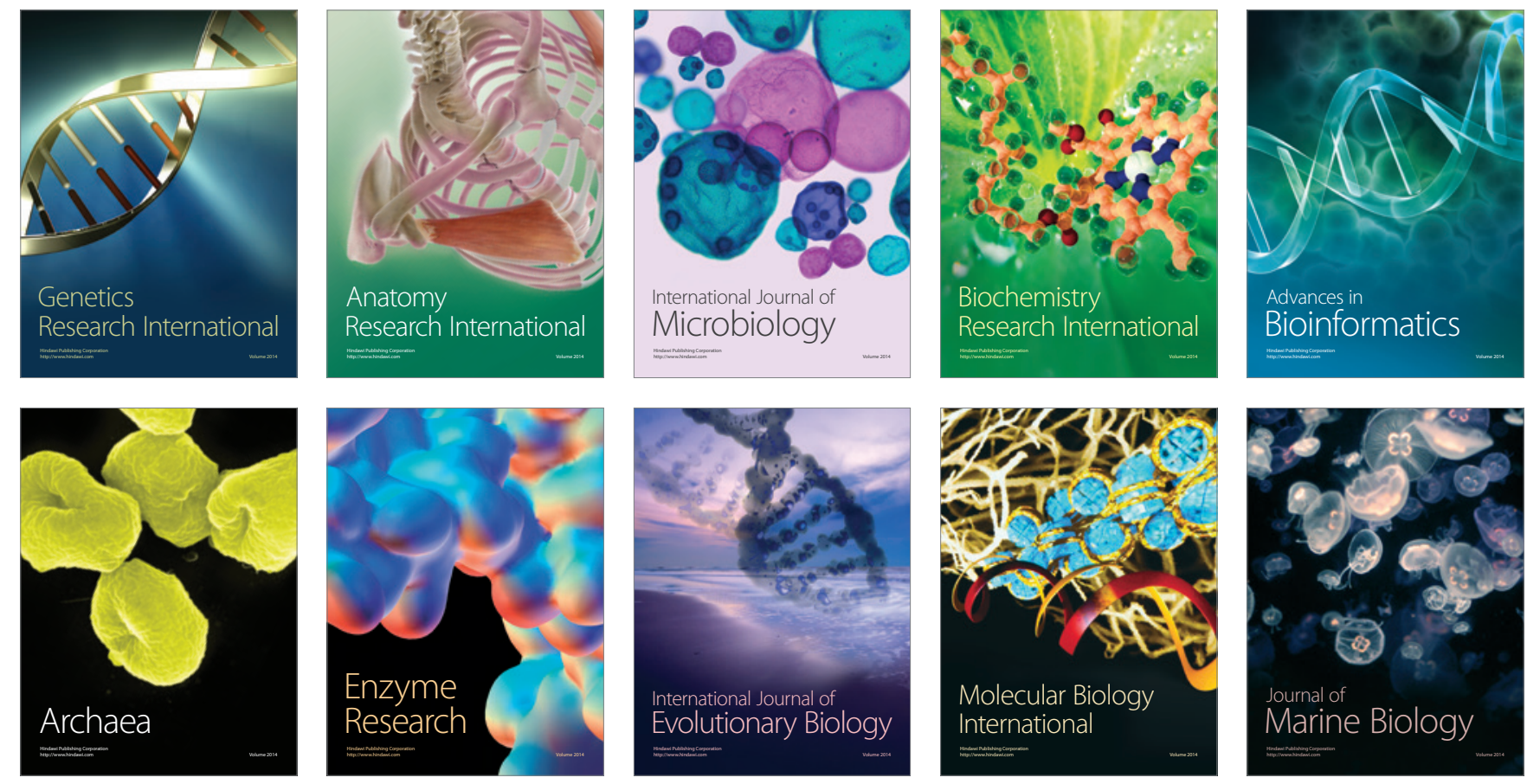